MaPan : Jurnal Matematika dan Pembelajaran

p-ISSN: 2354-6883 ; e-ISSN: 2581-172X

Volume 8, No 2, Dec 2020 (300-297)

DOI: https://doi.org/10.24252/mapan.2020v8n2a9

\title{
MATHEMATICAL COMMUNICATION SKILLS BASED ON GENDER
}

\author{
Dimas Alfarisyi ${ }^{1)}$, Sugeng Sutiarso ${ }^{2}$ \\ 1,2Magister Pendidikan Matematika, Universitas Lampung \\ 1,2Jl. Prof. Dr. Sumantri Brojonegoro, Gedong Meneg, Kec. Rajabasa, Kota Bandar \\ Lampung, Lampung \\ E-mail: dimas.alfarisyi38@gmail.com¹), sugengsutiarso7@gmail.com²)
}

Received April 07, 2020; Revised June 02, 2020; Accepted December 30, 2020

\begin{abstract}
This study was aimed to describe the mathematical communication skill of eighthgrade students of SMP IT Insan Mulia of Batanghari based on gender in solving questions about circle material. The subjects of this study consisted of 21 male and 21 female students. The research method used is descriptive qualitative. The data collection instrument used in this study is the mathematical communication skill test. The mathematical communication skill test instrument consists of three questions in the form of an essay. The results showed that in general, the mathematical communication skills of male and female students are in a low category. The low ability of students' mathematical communication is due to a weak understanding of concepts, not understanding the usefulness of mathematical symbols, and students' unfamiliarity in working on problems. Male and female students have different mathematical communication skills. Female students have better communication skills than male students in conveying ideas to provide an explanation on each indicator of the mathematical communication skills test.
\end{abstract}

Keywords: Mathematical Communication Skills, Gender, Circle Material

\section{KETERAMPILAN KOMUNIKASI MATEMATIKA BERDASARKAN GENDER}

\begin{abstract}
Abstrak
Penelitian ini bertujuan untuk mendeskripsikan keterampilan komunikasi matematis siswa kelas VIII SMP IT Insan Mulia Batanghari berbasis gender dalam menyelesaikan soal materi lingkaran. Subjek penelitian ini terdiri dari 21 siswa laki-laki dan 21 siswa perempuan. Metode penelitian yang digunakan adalah deskriptif kualitatif. Instrumen pengumpulan data yang digunakan dalam penelitian ini adalah tes keterampilan komunikasi matematis. Instrumen tes keterampilan komunikasi matematis terdiri dari tiga soal berbentuk essai. Hasil penelitian menunjukkan bahwa secara umum kemampuan komunikasi matematis siswa laki-laki dan perempuan berada pada kategori rendah. Rendahnya kemampuan komunikasi matematis siswa disebabkan karena pemahaman konsep yang lemah, kurang memahami kegunaan simbol matematika, dan ketidakbiasaan siswa dalam mengerjakan soal. Siswa laki-laki dan perempuan memiliki kemampuan komunikasi matematis yang berbeda. Siswa
\end{abstract}


perempuan memiliki kemampuan komunikasi yang lebih baik daripada siswa laki-laki dalam menyampaikan ide dengan memberikan penjelasan pada setiap indikator tes keterampilan komunikasi matematis.

Kata Kunci: Keterampilan Komunikasi Matematis, Gender, Materi Lingkaran

How to Cite: Alfarisyi, D. \& Sutiarso, S. (2020). Mathematical Communication Skills Based on Gender. MaPan : Jurnal Matematika dan Pembelajaran, 8(2), 300-314. https://doi.org/10.24252/mapan.2020v8n2a9.

\section{INTRODUCTION}

$\mathrm{M}$ athematics is a basic science that must be introduced early to be mastered by students. This is one of the important lessons that must be introduced in both formal and non-formal education (Murtafiah, 2016: 293; Rizta \& Antari, 2018: 293). One of the objectives of introducing mathematics is students will be able to solve problems by using symbols or language in mathematics. This is following the opinion of Pratiwi (2015: 132) who stated that mathematical language can be used to explore and consolidate to make development in solving problems. It shows that mathematics is an important lesson for students to master because there are mathematical symbols that can represent a problem so that it is easy to solve.

The ability to represent a problem by using the mathematical symbol is one part of mathematical communication skills. Lestari and Yudhanegara (2015: 83) stated that the ability of mathematical communication is the ability to convey, understand, and accept an idea both verbally or written carefully, analytically, critically, and evaluatively. Mathematical communication skills can be seen from several indicators and aspects. Baroody (1993: 107) explained mathematical communication skills have 5 aspects namely representing, listening, reading, discussing, and writing. Representing is the ability of students to use mathematical symbols or language to solve a problem. Listening is the ability of students to receive ideas carefully from the teacher or other students. So that it will train someone to have a critical and careful attitude in giving opinions. Reading is the ability to understand the contents of a question well. Discussing is the ability of students to express their opinions directly from a problem well. Writing is the students' ability to convey their ideas in written form. NCTM (1989: 64) stated that the indicators of students' mathematical communication skills are the ability of students to convey their ideas and draw them in writing, the ability of students to understand, interpret, and examine a 
problem from a picture, and the ability of students to use mathematical language or symbols to create mathematical models, draw relationships and convey an explanation of a problem.

Every student has different mathematical communication skills. One of the factors that influence it is gender. Hodiyanto (2017) stated gender is one of the factors influencing students' mathematical communication skills. Based on research by Untarti and Subekti (2016) stated that males have better abilities in presenting problems in diagram form and females have better abilities in providing explanations of problems. Besides, Cahyono (2017: 50) argued that the critical thinking skills of female students are better than male students. Some of these studies show there are differences when viewed by gender. Whether it will be the same if done in a different school.

Some schools divide each class at each level on a different basis. One of them is based on gender differences. SMP IT Insan Mulia Batanghari is a school that places students in each class based on gender. Male and female students in the school are placed in different classes or male students are not in the same class as female students. For this reason, this study was conducted with the aim of providing information about students' mathematical communication skills based on gender differences.

\section{METHODS}

This research is a qualitative descriptive study. The subjects of this study were students of class VIII SMP IT Insan Mulia Batanghari. The number of VIII grade students was 42 students consisting of 21 male students and 21 female students. The data collection used is a test. The test of mathematical communication skills consists of 3 questions in the form of an essay. The indicators of mathematical communication skills used are the ability of students to submit their ideas and draw them in writing, the ability of students to understand, interpret and examine a problem from a picture, and the ability of students to use mathematical language or symbols to create mathematical models, draw relationships, and convey explanations from a problem.

The procedure in this study has three stages, namely plan, data collection, and data analysis. The preparation of mathematics communication skills tests questions is carried out at the planning stage. However, before the written test is given, it is validated first to assess whether the written test has met the valid criteria or not. The questions that have been made are given to students to work on. The results of student work are recorded and collected. 
Furthermore, after the data is collected, data analysis is performed. The analysis of the data used is descriptive qualitative analysis. The mathematical communication skills of students are categorized based on the classification of the following table.

Table 1. The Criteria for Mathematical Communication Skills

\begin{tabular}{cc}
\hline Score & Criteria \\
\hline $\mathbf{8 5} \leq \mathbf{S} \leq \mathbf{1 0 0}$ & Very good \\
$\mathbf{7 0} \leq \mathbf{S}<\mathbf{8 5}$ & Good \\
$\mathbf{6 5} \leq \mathbf{S}<\mathbf{7 0}$ & Enough \\
$\mathbf{5 5} \leq \mathbf{S}<\mathbf{6 5}$ & Poor \\
$\mathbf{5 5}<\mathbf{S}$ & Very Poor \\
\hline
\end{tabular}

\section{RESULTS AND DISCUSSION}

Based on the mathematical communication skills test instrument that has been done by eighth-grade students, the following results were obtained:

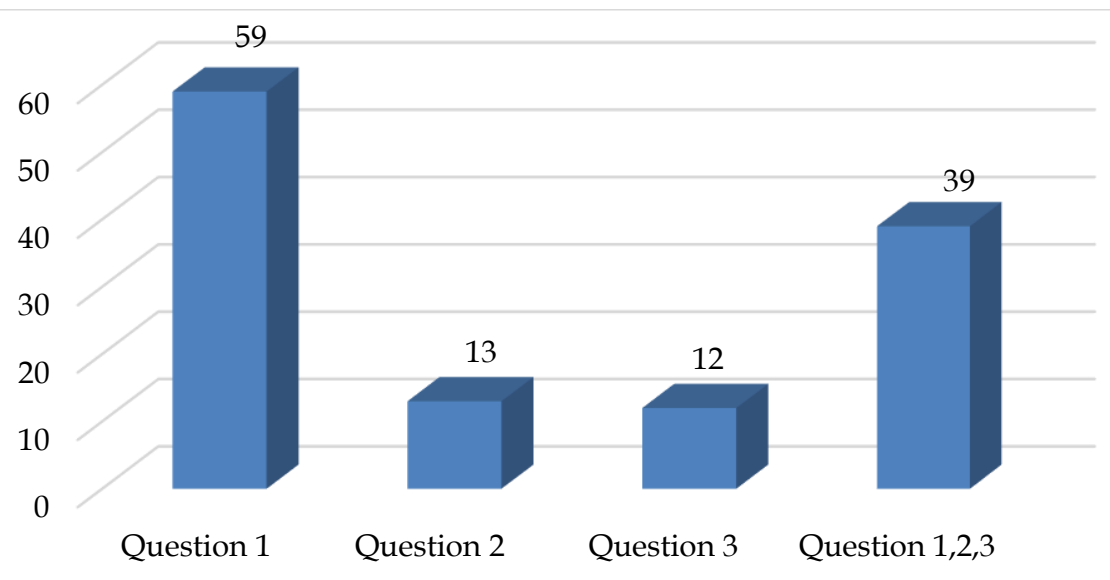

Figure 1. Student's Mathematical Communication Skills Scores

Based on figure 1, the following is a score of students in working on mathematical communication skills test questions consisting of three questions. Student scores in working on the questions on indicator 1 are 59 which is in the poor category. The score of mathematical communication ability on indicator 2 is 13 which is in the very poor category and the score of mathematics communication skills on indicator 3 is 12 which is in the very poor category. So overall the score of students' mathematical communication skills is 39 which is in the very poor category. The following is presented in more detail the results of a mathematical communication ability test-based on gender consisting of 21 male students and 21 female students. 


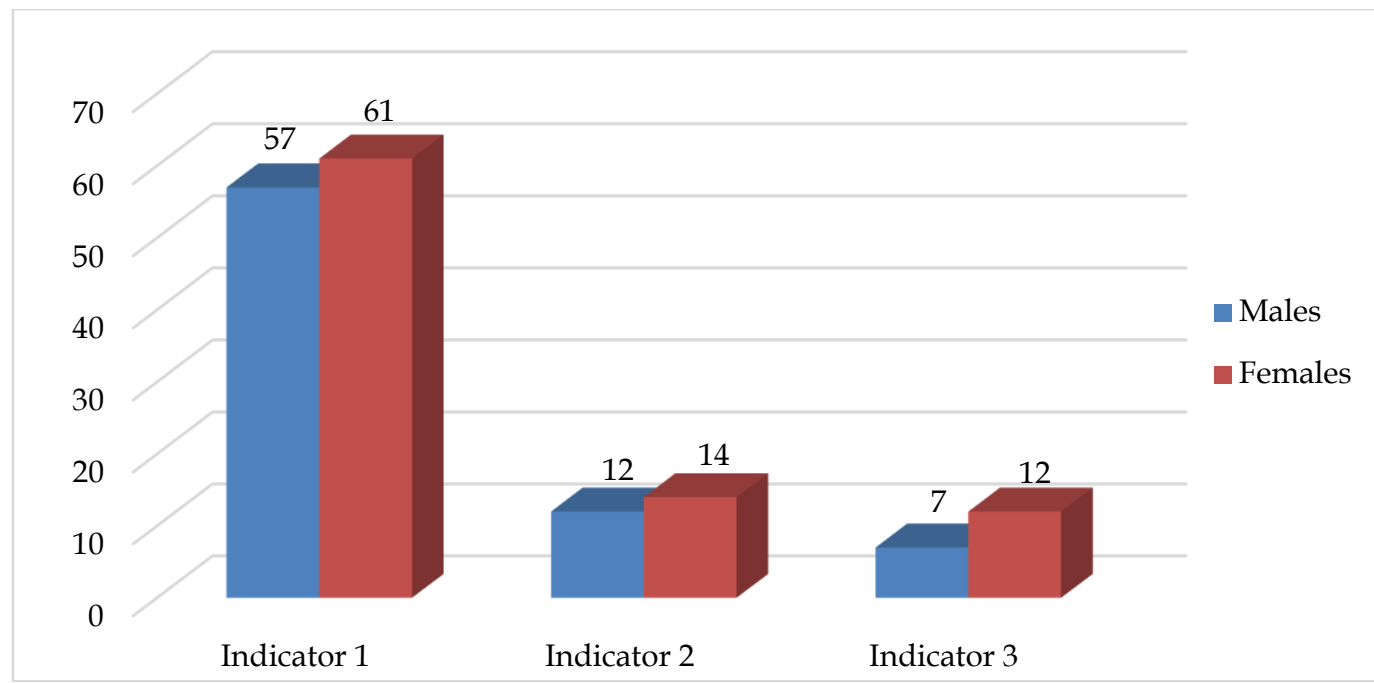

Figure 2. The Average Score of Students' Mathematical Communication Skills

Based on Gender

Description:

Indicator 1 : The ability of students to express their ideas and draw it in writing.

Indicator 2 : The ability of students to understand, interpret, and examine a problem from an image.

Indicator 3 : The ability of students to use language or mathematical symbols to make mathematical models, draw relationships, and convey explanations of problems.

Based on figure 2, we can know that the mathematical communication skills of female students are higher than male students on each indicator. Students' mathematical communication skills on the indicator, "The ability of students to express their ideas and draw it in writing," is higher 4, on the indicator of "The ability of students to understand, interpret and examine a problem from an image," is higher 2, and on the indicator of "The ability of students to use language or mathematical symbols to make mathematical models, draw relationships and convey explanations of problems," is higher 5 . The following are the results and explanations for each indicator of students' mathematical communication skills.

Indicator 1 : The ability of students to express their ideas and draw it in writing. 
Question 1 : It is known that circle $\mathrm{O}$ has a diameter of $10 \mathrm{~cm}$ and has a central angle of $\mathrm{AOB} 120^{\circ}$ and a circumference angle of $\mathrm{ACB}, \mathrm{ADB}$, and AEB.

a. Draw the circle and determine the size of $\angle$ AEB!

b. Is there a big relationship between the central angle and the lean angle? Explain it!

Based on the mathematical communication skills test instrument on "The ability of students to express their ideas and draw it in writing," the following is displayed the total of students who got scores $0,1,2.3$, and 4 .

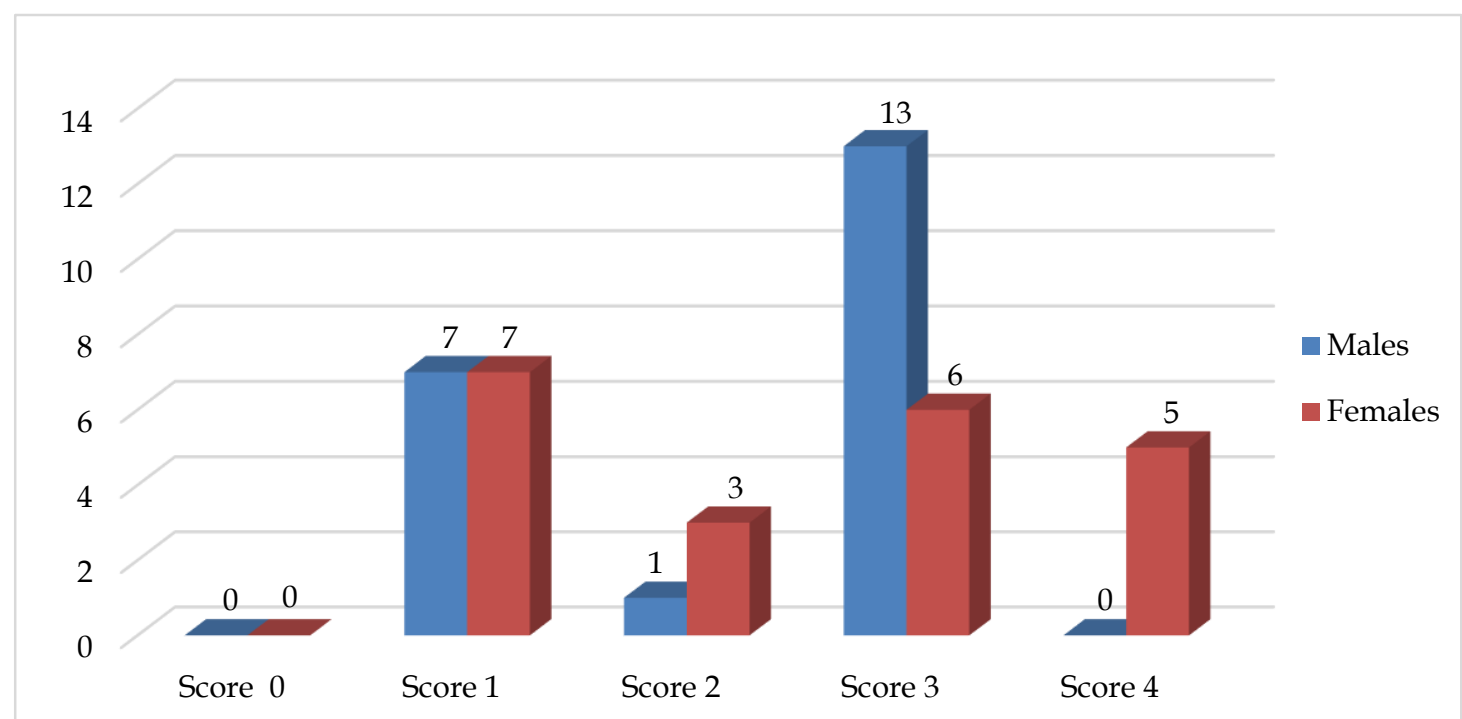

Figure 3. The Total of Students Getting Scores of 0, 1, 2, 3, and 4 at Question Number 1

Based on figure 3, we can see that female student have the ability to express ideas verbally, in writing and demonstrate in a better visual form in answering and giving explanations from male students. This can be seen from the results obtained score; from 21 female students, there are five female students who got the highest score (4). While, from 21 male students, there is no student who got 4 . The highest score was got by 3 male students. The following is displayed the work of male and female students who get the highest score on indicator 1. 


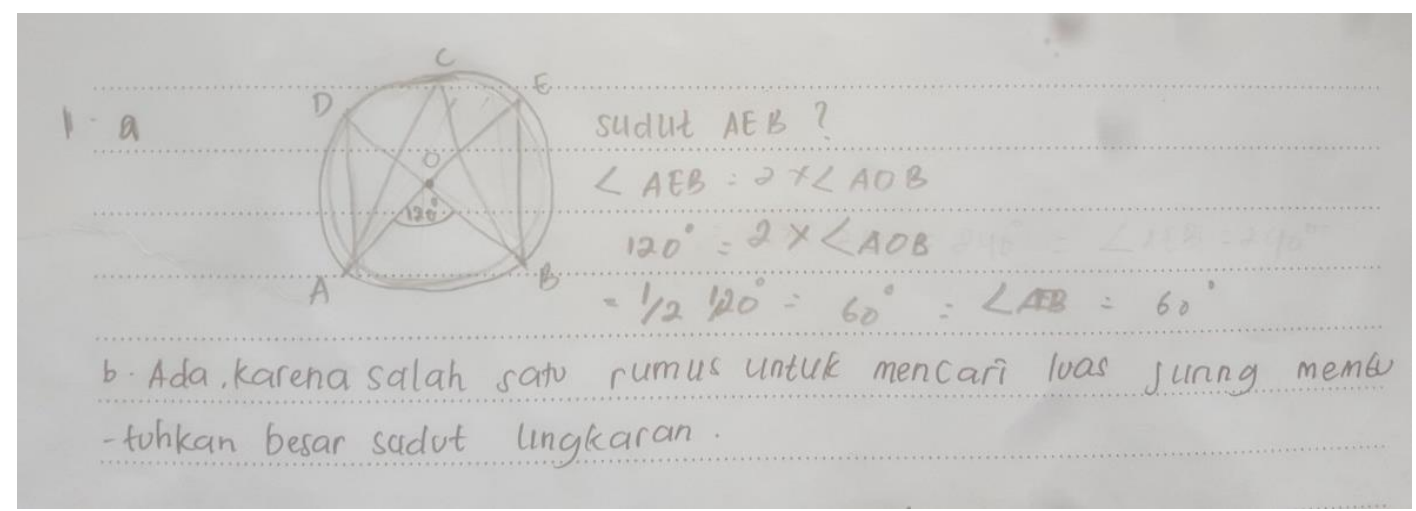

Figure 4. The Male Students' Answer at Question Number 1

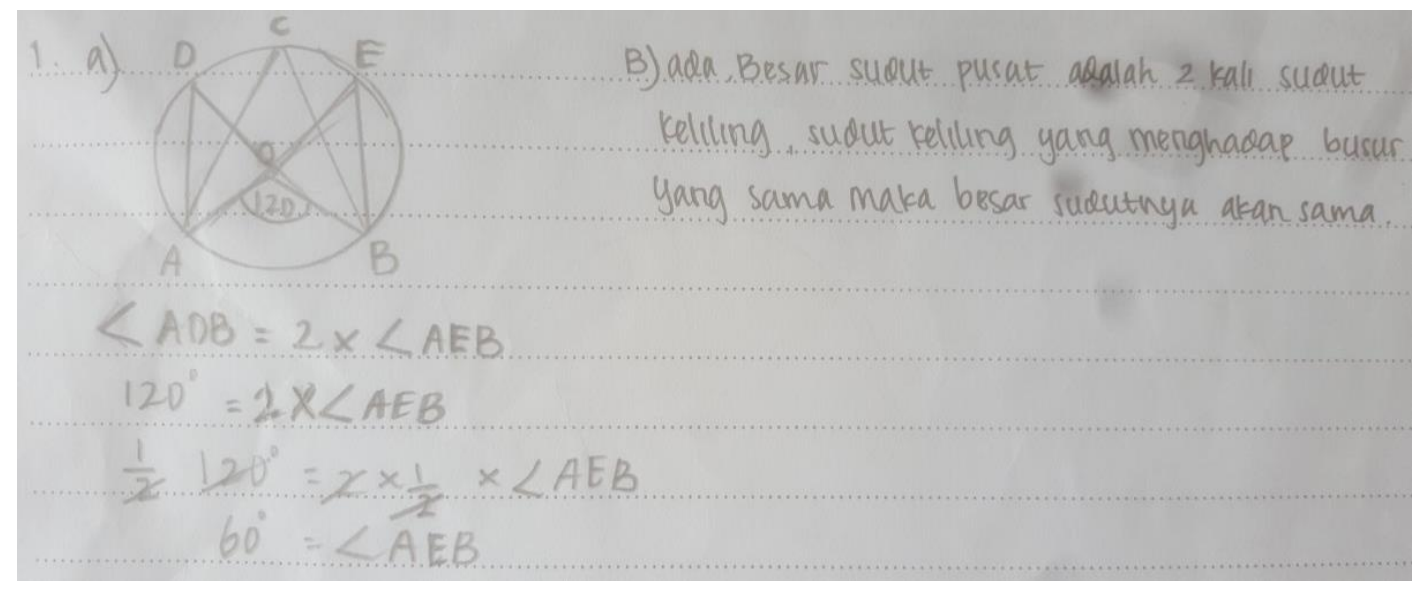

Figure 5. The Female Students' Answer at Question Number 1

Based on the answers of male and female students on indicator 1 namely, "The ability of students to express their ideas and draw it in writing," male and female students can draw a circle and determine the angle size of $\angle \mathrm{AEB}$. But in providing an explanation of the relationship between the central angle and the circumferential angle, female students can explain precisely with the explanation that the magnitude of the central angle is 2 times of the circumferential angle. The explanation of male students is not right because it does not link between the large central angle and the circumferential angle in the circle. In providing an explanation of the relationship between the central and peripheral angles, students must understand the concept well and be able to explain the relationship in written form.

Indicator 2 : The ability of students to understand, interpret, and examine a problem from an image.

Question 2 : Please look at the following picture: 


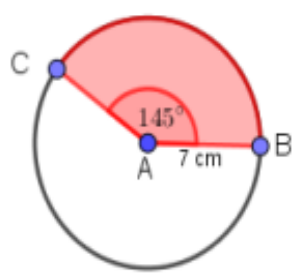

A

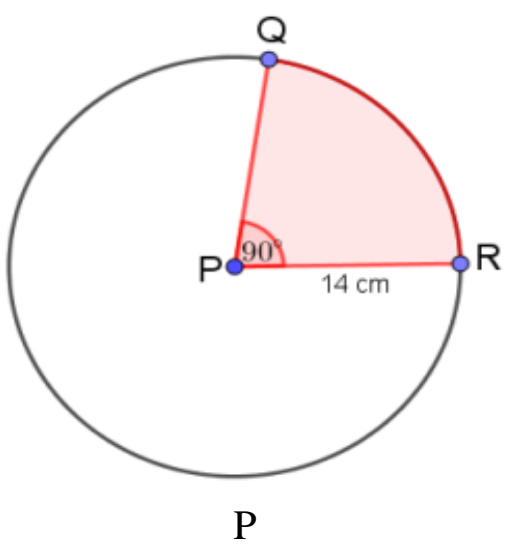

From the pictures of Circles $\mathrm{A}$ and $\mathrm{P}$, please determine:

a. The large section area of circle A and circle P!

b. Is there a relationship between a large angle with the area of the circle on the circle? Explain it!

Based on the mathematical communication skills test instrument on indicators of "The ability of students to understand, interpret, and examine a problem from an image," the following is displayed the total students who got scores $0,1,2,3$, and 4 .

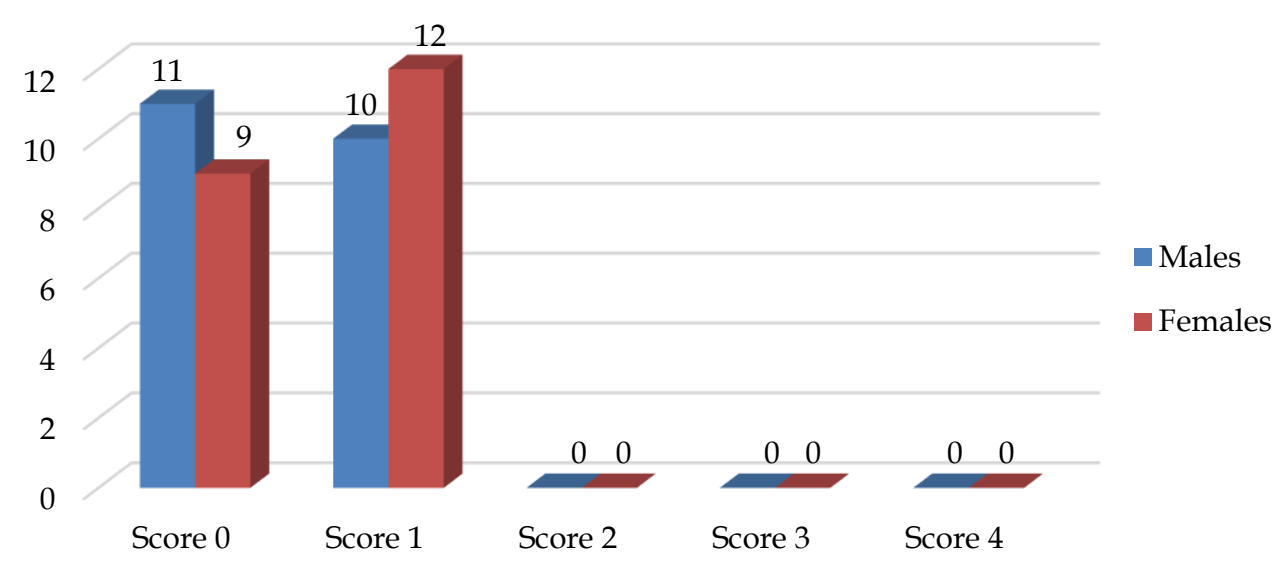

Figure 6. The Total of Students Getting Scores of 0, 1, 2, 3, and 4 at Question 2

Based on figure 6, we can see that the indicators of "The ability of students to understand, interpret and examine a problem from an image," female or male students still have difficulty in solving the problem. This can be seen from the acquisition of the highest score obtained, namely male and female students only got the highest score (1). The number of students who got a score of 1 was more dominant to female students. The following is displayed the work result of male and female students who got the highest score on indicator 2. 


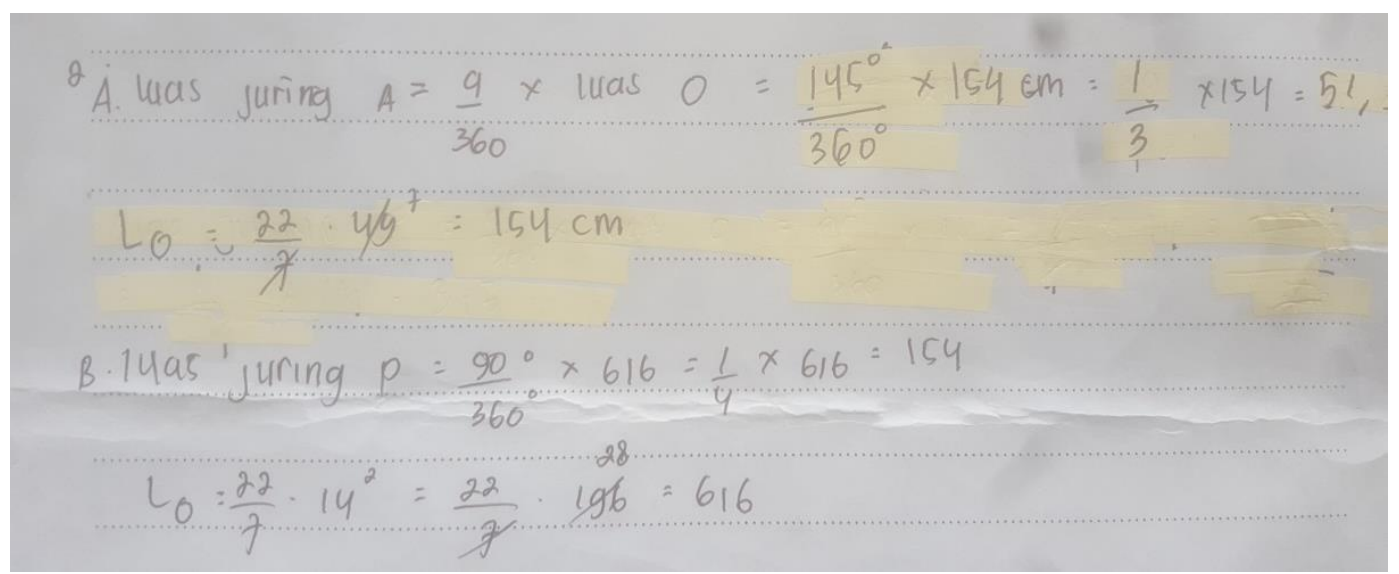

Figure 7. The Male Students' Answer at Question Number 2

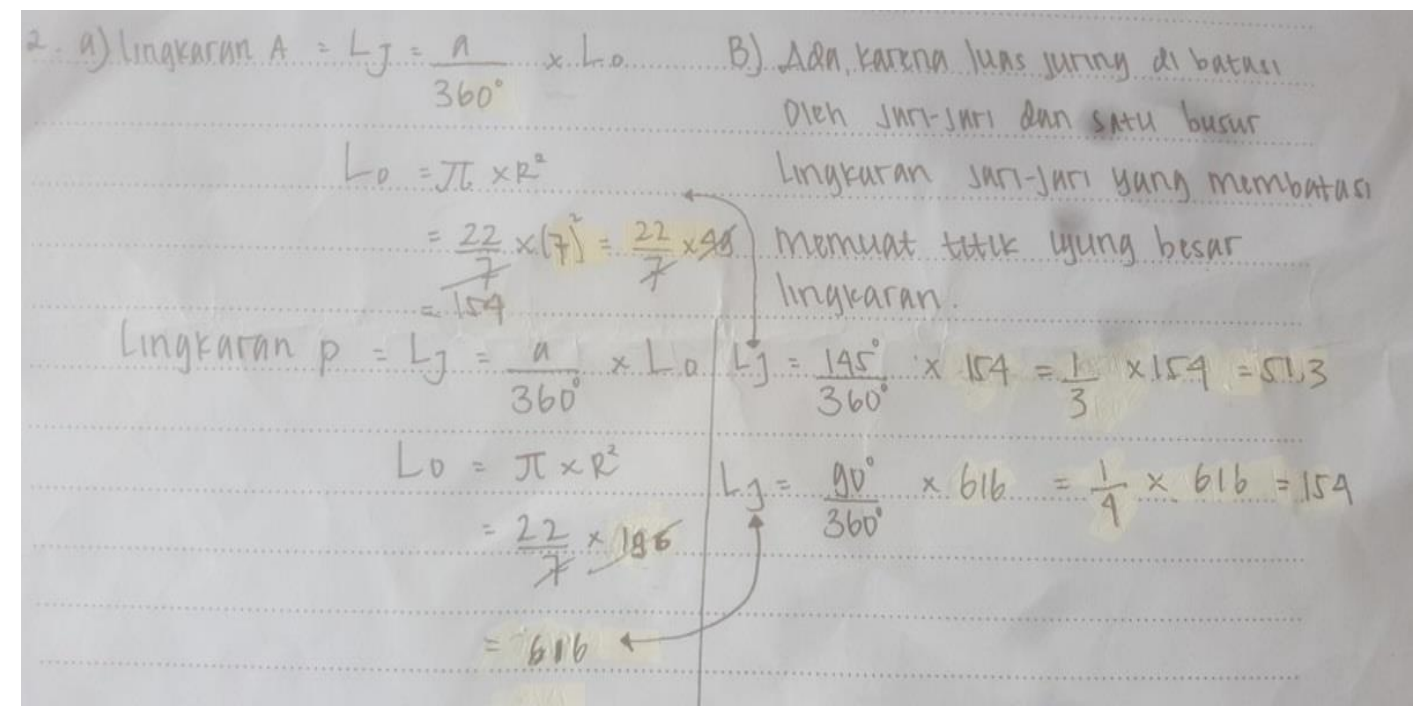

Figure 8. The Female Students' Answer at Question Number 2

Based on the answers of male and female students in indicator 2, male and female students can understand the picture in the problem well, it can be seen from the answers of students who know the length of the radius and the size of the circle A and circle P. The male students in determining the area of the segment in circle A and circle P did errors in operating algebra so students' answers were incorrect. Male students also cannot evaluate to explain the relationship between the size of the segment in the circle. While female students only have errors in operating the algebraic form in determining the width of the A circle's segment. Female students also explain the relationship between the area of the width of the circle's segment, even though the explanation is incorrect the female student can represent the idea in written form. To answer the wide area of circle A and P, firstly, students understand the concept of the width of 
the circle's segment, so the students can determine the size of the circle's segment and give an explanation of the relationship of the width of the circle's segment well. In addition, the lack of carefulness of students in performing algebraic arithmetic operations causes the calculation of the area of the segment to be incorrect.

Indicator 3 : The ability of students to use language or mathematical symbols to make mathematical models, draw relationships, and convey explanations of problems.

Question 3 : A running championship will be held at the Bung Karno Stadium.

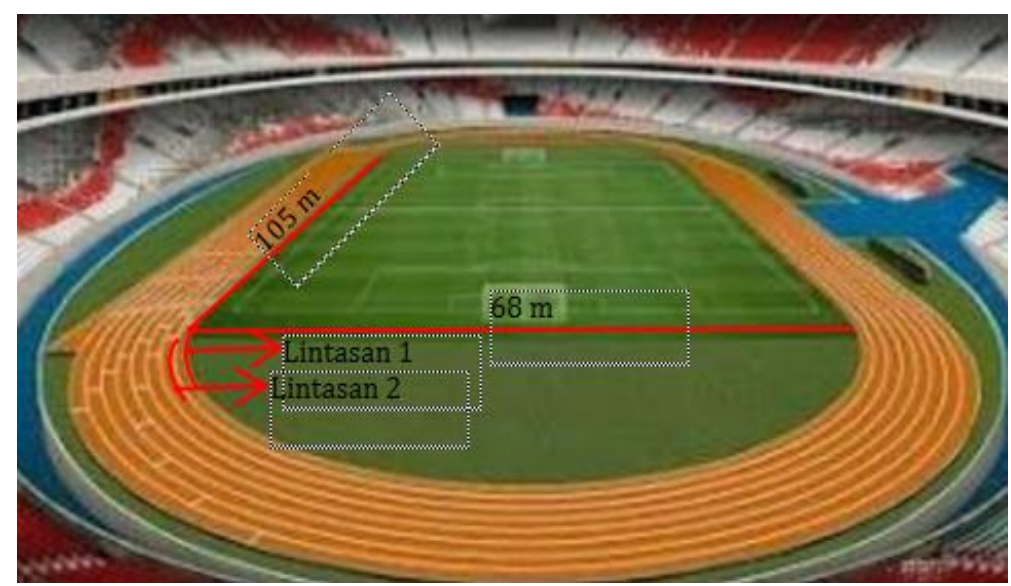

If the distance of each track is $100 \mathrm{~cm}$. Please determine:

a. How long are the length of lane 1 and lane 2?

b. If the race that will be held is an $800 \mathrm{~m}$ run. Will lane 1 , lane 2 , and lane 8 have the same start and finish lines? Please explain it well.

Based on the test instrument, "The ability of students to use language or mathematical symbols to make mathematical models, draw relationships and convey explanations of problems," the following is shown the number of students who got scores $0,1,2,3$, and 4 . 


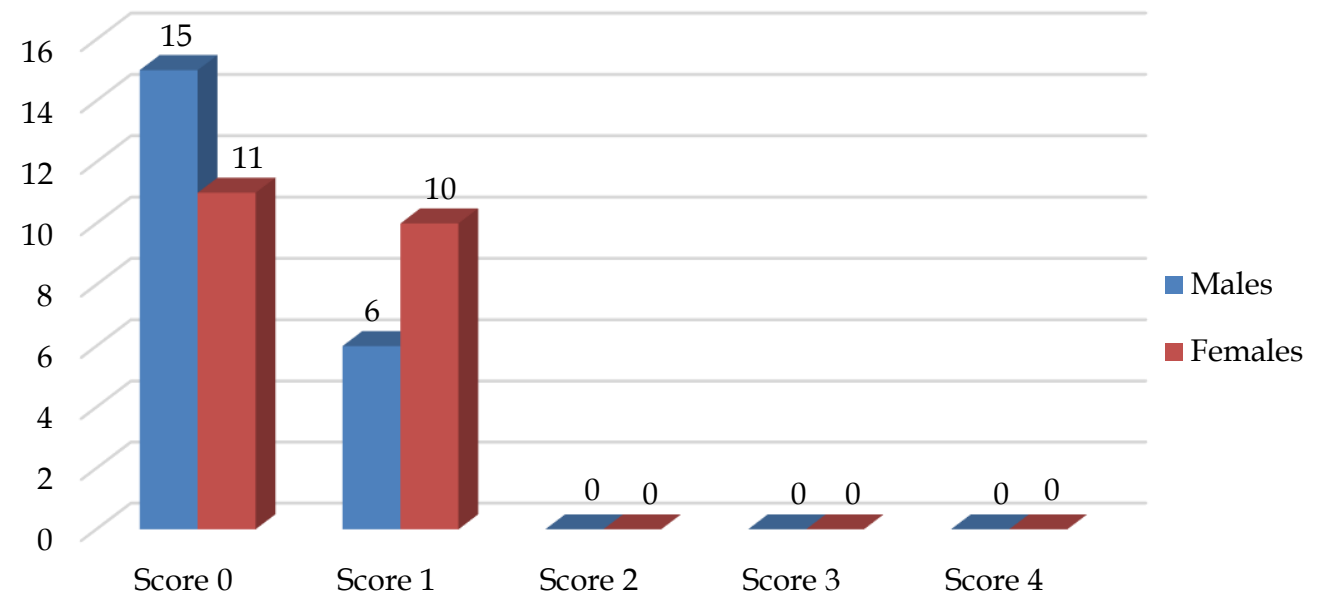

Figure 9. The Total of Students Getting Scores of 0, 1, 2, 3, and 4 at Question 3

Based on figure 9 we can see that ability of students to use language or mathematical symbols to make mathematical models, draw relationships, and convey explanations of problems is still very low. This can be seen from the number of students who did not answer the questions and the answers given were not right so that the maximum score obtained by students was only 1 . The following is displayed the work result of male and female students who received the highest score on indicator 3 .

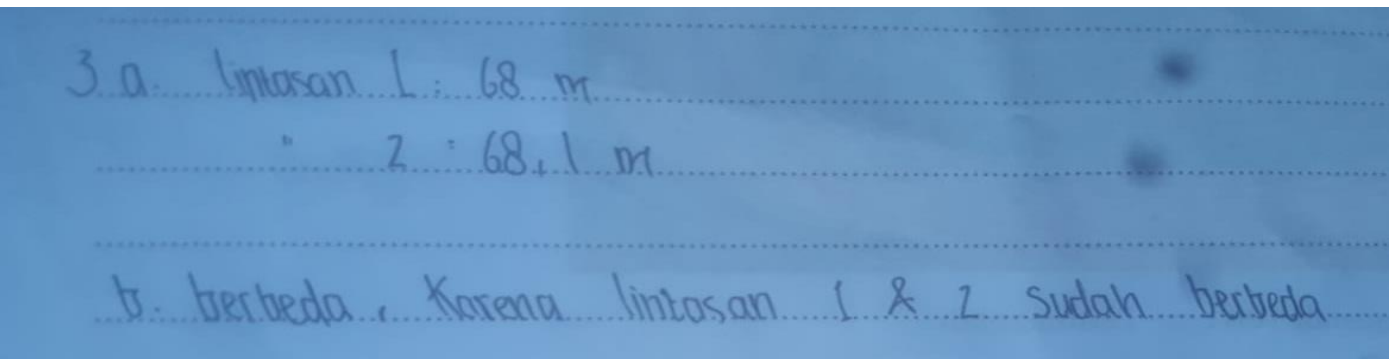

Figure 10. The Male Students' Answer at Question Number 3

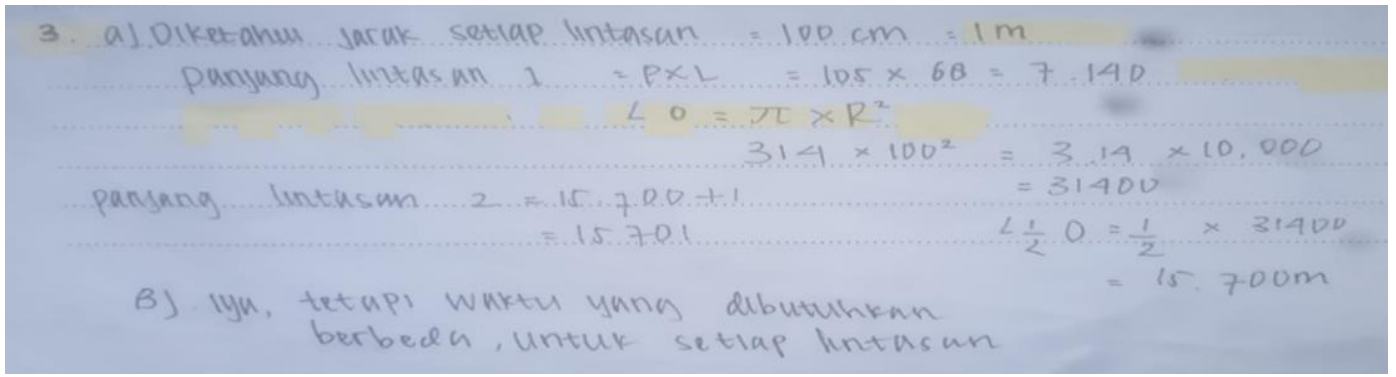

Figure 11. The Female Students' Answer at Question Number 3 
Based on the answers of male and female students in indicator 3, male and female students got difficulty in answering questions. The male students immediately answered the length of the lane without using the notation of terms, mathematical notations, and their structures to present ideas, describe relationships and situational models. Also, in giving explanations male students just explain without connecting them with concepts in mathematics. So the answers and explanations of male students were incorrect. Female students have already used mathematical notations, and their structures to present ideas, but they were not able to explain precisely the reasons whether lane 1, 2 until 8 have the same start and finish line. This is because students did not fully understand the picture so they experienced errors in determining the length of the radius. In working on the problem, students should first pay close attention to and understand the picture at the question, then use mathematical notations and symbols. To determine the length of lane one we can find the area width of a square with the formula $p \times 1$ and the area width of a circle with the formula $\pi r^{2}$.

Based on the discussion found several causes of low mathematical communication skills of male and female students. Most male and female students who do not answer questions are because students cannot understand the questions well. That is because students' understanding of concepts is poor and students are not used to working on problems with mathematical communication skills. In addition, students also lack an understanding of symbols in mathematics and their functions. So, when they solve the problems, they cannot model them. This is following the statement of Thalhah (2014: 89), namely concerning mathematics for the scientific world, mathematics has a role as a symbolic language that allows accurate and precise communication.

Female students have better abilities in providing explanations or representing ideas in each indicator of students' mathematical communication skills. This is in line with the opinion of Zakiri, Pujiastuti, and Asih (2018: 83) and Kusumaningsih, Saputra, and Aini (2018: 5) which stated that female students have better abilities in repressing ideas, models, and conveying ideas. This can be seen from the answers of female students who can explain their ideas using their language in answering questions. While only a few male students provide an explanation in answering questions. That is caused by the different habits of male and female students. In everyday life, female students prefer to speak, which indirectly trains communication skills. Whereas male students have the habit of only speaking as needed in the learning process. 
Female students are more careful and systematic in answering questions. This allows female students to understand the question well. So that female students have good and well-prepared planning in answering questions (Yuliana \& Winarso, 2019: 58). Those make their answers are more systematic than those of male students' answers.

The difference in students' mathematical communication skills is due to several factors. One of the factors that cause different mathematical communication skills between male and female students in different ways of thinking in solving a problem. Based on research conducted by Wahyuningsih, Sani, and Sudia (2019) states that students thinking processes in solving a problem have different characteristics seen from cognitive and gender styles (Nurhayati \& Aripin, 2020: 105). Sutiarso (2019: 65) stated that one of the causes of these differences is due to the different brain anatomy of males and females. These differences cause male and female students to have different perspectives on solving problems. Male students tend to be as they do the work and they do not talk too often. Those cause students to have difficulty in conveying ideas.

Based on the above discussion, mathematical communication skills are important and must be developed in students. Istikomah (2014: 66) states that mathematical communication skills can support other mathematical abilities, such as problem-solving abilities. Therefore mathematical communication must be own and be expanded to students in solving the problem at hand (Lanya, Zayyadi, Aini, \& Haris 2020: 15). With having good mathematical communication skills, a problem will be represented and this will support problem-solving.

\section{CONCLUSION}

Based on the results of the analysis and discussion, it can be concluded that in general, the mathematical communication skills of male and female students are in the poor category. This is due to a weak understanding of concepts, not understanding the usefulness of mathematical symbols, and students' unfamiliarity in working on problems. Male and female students have different mathematical communication abilities. Female students have better communication skills than male students in conveying ideas to provide an explanation on each indicator of the mathematical communication skills test. 


\section{REFERENCES}

Baroody, A. J. (1993). Problem solving, reasoning, and communication. New York: Machmillan Publishing.

Cahyono, B. (2017). Analisis keterampilan berfikir kritis dalam memecahkan masalalah ditinjau dari perbedaan gender. AKSIOMA : Jurnal Matematika Dan Pendidikan Matematika, 8(1), 50-64. https://doi.org/ 10.26877/aks.v8i1.1510.

Hodiyanto, H. (2017). Pengaruh Model pembelajaran problem solving terhadap kemampuan komunikasi matematika. Jurnal Riset Pendidikan Matematika, 4(2), 219-228. https:// doi.org/10.21831/jrpm.v4i2.15770.

Istikomah, D. A. (2014). Upaya peningkatan kemampuan komunikasi matematis siswa dengan model pembelajaran kooperatif di SMPN 2 Sedayu Yogyakarta. AKSIOMA Journal of Mathematics Education, 3(2), 6576. https://doi.org/10.24127/ajpm.v3i2.333.

Kusumaningsih, W., Saputra, H. A., \& Aini, A. N. (2018). Cognitive style and gender differences in a conceptual understanding of mathematics students. Journal of Physics Conference, 1280, 1-6. https://doi.org/10. 1088/1742-6596/1280/4/042017.

Lanya, H., Zayyadi, M., Aini, S. D., \& Haris. (2020). Mathematic communication skills in senior high school based on gender differences. Pi: Mathematics Education Journal, 3(2), 15-21. https://doi.org/10.21067/ pmej.v3i2.4718.

Lestari, K. E., \& Yudhanegara, M. R. (2015). Penelitian pendidikan matematika. Bandung: Reflika Aditama.

Murtafiah, W. (2016). Kemampuan Komunikasi Matematika Mahasiswa Calon Guru Matematika dalam Menyeesaikan Masalah Pesamaan Diferensial Ditijau dari Gender. Jurnal Math Educator Nusantara, 2(1), 31-41. Retrieved from https://ojs.unpkediri.ac.id/index.php/matematika/ article/view/399.

NCTM. (1989). Curriculum and evaluation standards for school mathematics. Reston, VA: NCTM.

Nurhayati, A. S., \& Aripin, U. (2020). Students thinking process in solving the problems of social arithmetic stories test based on gender. MaPan : Jurnal Matematika Dan Pembelajaran, 8(1), 103-113. https://doi.org/10.24252/ mapan.2020v8n1a8.

Pratiwi, D. D. (2015). Analisis kemapuan komunikasi matematik dalam pemecahan masalah matematik sesuai dengan gaya kognitif dan gender. Al-Jabar : Jurnal Pendidikan Matematika, 6(2), 131-142. https:// doi.org/ 10.24042/ajpm.v6i2.28.

Rizta, A., \& Antari, L. (2018). Pengembangan tes kemampuan komunikasi matematis pada materi sistem persamaan linear untuk mahasiswa calon guru matematika. AKSIOMA: Jurnal Matematika Dan Pendidikan Matematika, 7(2), 291-299. https:/ /dx.doi.org/10.24127/ajpm.v7i2.1525. 
Sutiarso, S. (2019). The ability of students' mathematical proof in an introduction to group theory in terms of gender differences. Jurnal Pendidikan MIPA, 20(2), 60-67. Retrieved from http:// repository.lppm. unila.ac.id/19852/.

Thalhah, S. Z. (2014). Peningkatan kemampuan komunikasi matematika melalui pembelajaran dengan pendekatan problem posing pada siswa Kelas X6 MAN Pinrang. MaPan : Jurnal Matematika Dan Pembelajaran, 2(1), 86-104. https://doi.org/10.24252/mapan.2014v2n1a7.

Untarti, R., \& Subekti, F. E. (2016). Kemampuan komunikasi matematik mahasiswa ditinjau dari gender pada materi telaah kurikulum SMP. Pyhtagoras: Jurnal Program Studi Pendidikan Matematika, 5(2), 139-150. https://dx.doi.org/10.33373/ pythagoras.v5i2.466.

Wahyuningsih, S., Sani, A., \& Sudia, M. (2019). Analisis proses berpikir siswa SMP dalam memecahkan masalah matematik ditinjau dari gaya kognitif dan gender. Jurnal Pembelajaran Berpikir Matematika, 4(1), 121-132. https://dx.doi.org/10.33772/jpbm.v4i1.7171.

Yuliana, Y., \& Winarso, W. (2019). Penilaian self efficacy dan kemampuan pemecahan masalah matematika berdasarkan perspektif gender. Mapan : Jurnal Matematika Dan Pembelajaran, 7(1), 41-60. https://doi.org/ 10.24252/mapan.2019v7n1a4.

Zakiri, I. K., Pujiastuti, E., \& T.S.N., A. (2018). The mathematical communication ability based on gender difference on students of XI grade by using problem based learning model assisted by probing prompting technique. Unnes Journal of Mathematics Education, 7(2), 78-84. https://doi.org/ 10.15294/ujme.v7i2.20645. 